\title{
China's Foreign Aid Policy and Architecture
}

\section{Lan Xue*}

\begin{abstract}
As China's engagement in low-income countries has deepened, particularly in Africa, so has criticism of China's development programmes and practices. New developments in Africa and the international aid architecture warrant a re-examination of China's foreign assistance and development architecture, and its capacity in managing this growing engagement. This article outlines the modes of Chinese foreign assistance, the institutional arrangements and the principles that guide it. It argues that, while China's foreign aid has been characterised by several strengths, including its practical orientation, its consistency of principles, and its focus on high-level exchanges, these same features may also be fault lines for both the future effectiveness of China's aid programmes, and its international reputation as a rising power in development. Evaluation and future reform of China's aid architecture is needed in order to enhance China's aid capacity and effectiveness.
\end{abstract}

\section{中国对外援助政策和体系}

薛澜

随着中国对低收入国家（尤其是非洲国家）的影响逐渐深入，中国的发展项目和活 动也受到越来越多的批评。非洲和国际援助体系的新发展趋势都要求重新审视中国 的对外援助政策、发展模式及其对自身活动的管理能力。本文概述了中国对外援助 的模式、体制设置和指导原则, 指出尽管中国对外援助具有以实用为导向、指导原 则前后一致、以高层交流为重点等优势，但这些特点也可能成为影响未来援助项目 和作为新兴国家国际声誉的劣势。中国援助体系需要进行评估和改革，从而加强其 效率和能力。 


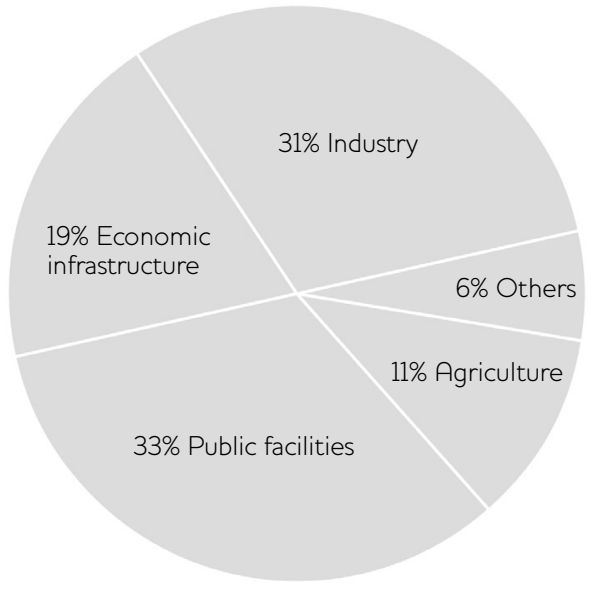

Source Author's own data sourced from China Commerce Yearbook. ${ }^{1}$

\section{Introduction}

China's foreign aid, particularly in Africa, has attracted considerable international attention in recent years. China's aid programme has been praised for its efficiency and implementation, when contrasted to the cumbersome processes traditionally associated with overseas development assistance, and for its capacity for technology transfer. For African governments disillusioned with the Western development model, China's development expertise gives them hope of a new path for development. However, China's aid programme has also received much criticism from the international development community and from civil society, who have argued that China's aid is driven by the need for energy and raw materials, and that China neglects human rights issues and governance in recipient countries. The lack of transparency around China's aid and also problems of local hostility towards Chinese workers and companies are also ongoing problems with China's aid delivery.

While these criticisms do not represent the entirety of China's aid programme, they do

Figure 2 China foreign assistance projects in Africa (2003-06)

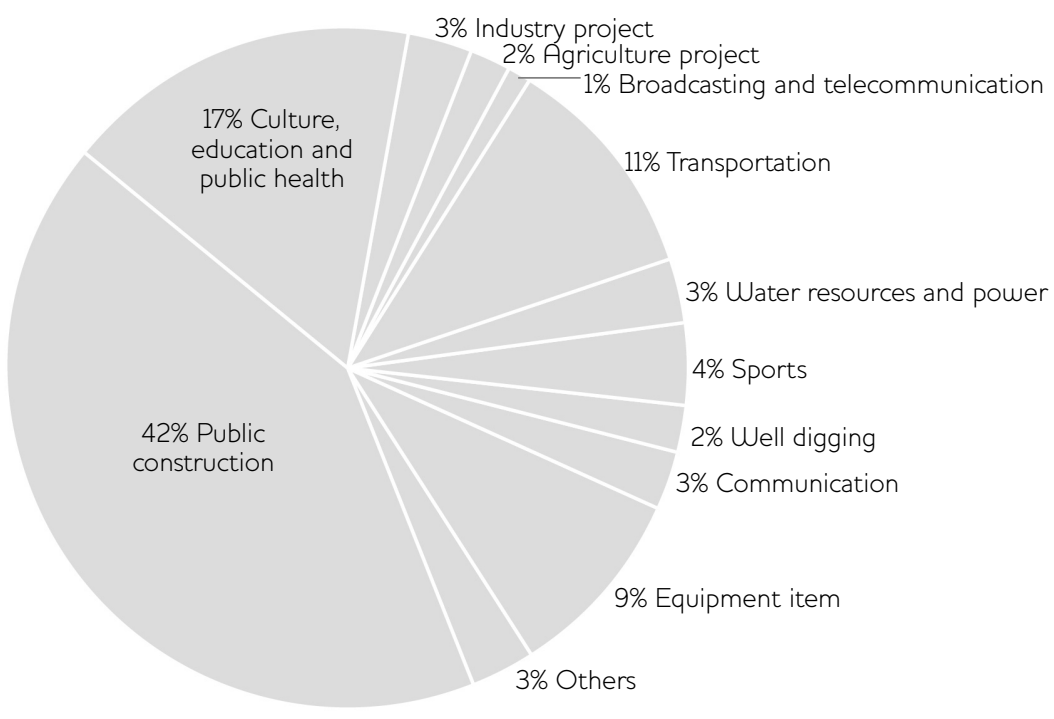

Source Author's own data sourced from China Commerce Yearbook. ${ }^{2}$ 


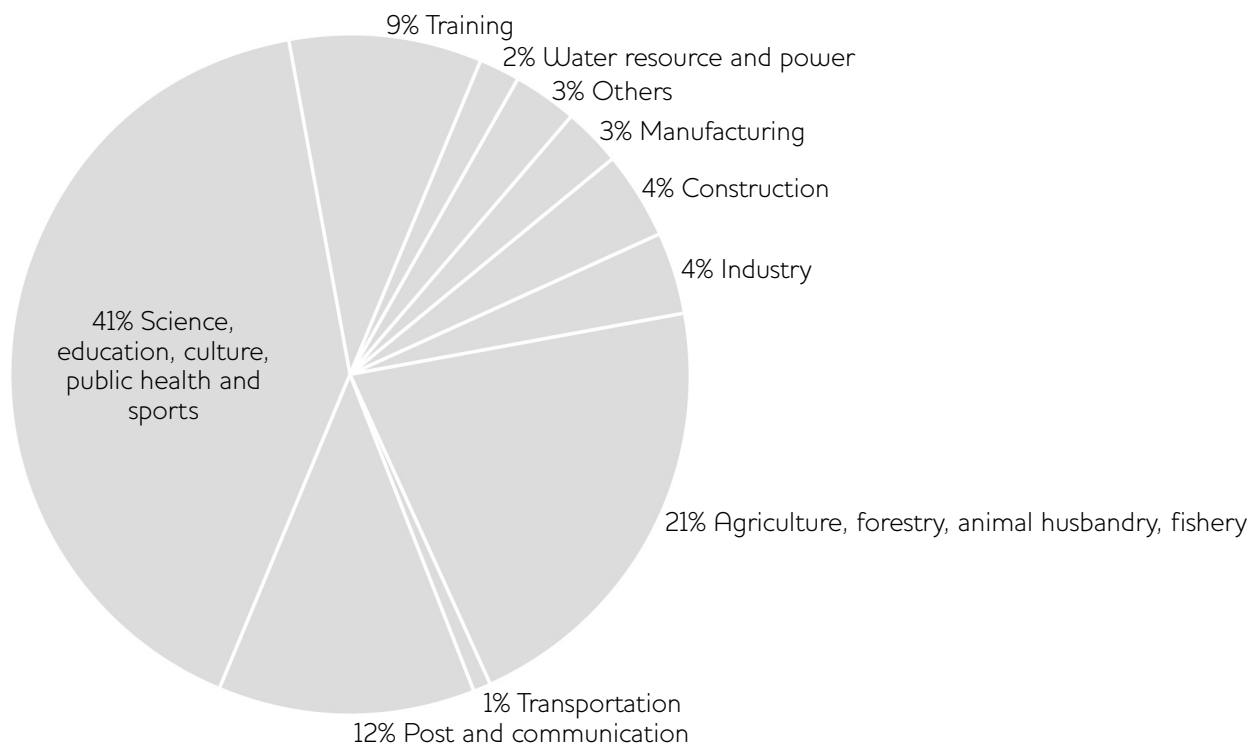

Source Author's own data sourced from China Commerce Yearbook. ${ }^{4}$

indicate fault lines that, left unchecked, may reduce the effectiveness of China's aid and hurt the long-term potential for China-Africa cooperation. With the rapid expansion of China's aid to Africa, there is a need to re-examine China's current aid architecture and capacity, as well as its conceptual principles. New developments in Africa and the international aid market also present challenges to the current practice of China's aid. These emerging issues warrant a systematic examination of China's current aid architecture and standards. This article, based on an International Development Research Centre (IDRC)-funded report of the same title, outlines the modes of Chinese foreign assistance, the institutional arrangements and the principles that guide it. It argues that, while China's foreign aid has been characterised by several strengths, including its practical orientation, its consistency of principles, and its focus on high-level exchanges, these same features may also become weaknesses for both the future effectiveness of China's aid programmes, as well as its international reputation as a rising power in development. Evaluation and future reform of China's aid architecture is urgently needed, in order to enhance China's aid capacity and effectiveness.

\section{China's aid and technical assistance}

The first official relationships between China and African countries began in 1956, when China established diplomatic relations with Egypt, and sent assistance through loans and volunteers during the Suez Crisis (Chen 2008). In the subsequent half-century, China's aid to African countries has made major strides. Since the late 1990s, the scale of China's partnership with Africa has expanded to involve a network of trade, aid and investment with over 50 African countries.

China provides aid mainly in the form of technical assistance (see Figures 1 and 2), with an emphasis on training, grants, interest-free loans and preferential loans that have an interest subsidy and debt relief. Simultaneously, China has largely eliminated tariffs on exports from 29 of the least developed African countries, and has become a source of foreign direct investment to Africa. As of 2006, Ghina's existing loans and credit lines to Africa are estimated to total about US $\$ 19$ billion (author's own data based on China Commerce Yearbook figures). ${ }^{3}$ The beneficiaries of the largest flows are Angola, Equatorial Guinea, Gabon, the Republic of Congo and Nigeria. Much of this assistance has been funnelled into projects for economic and social infrastructure such as roads, telecommunications, hospitals and health-care delivery; knowledge-sharing, including government scholarship programmes for 50 African countries; the productive sector, notably agriculture; and construction, including government buildings and sports stadiums. 


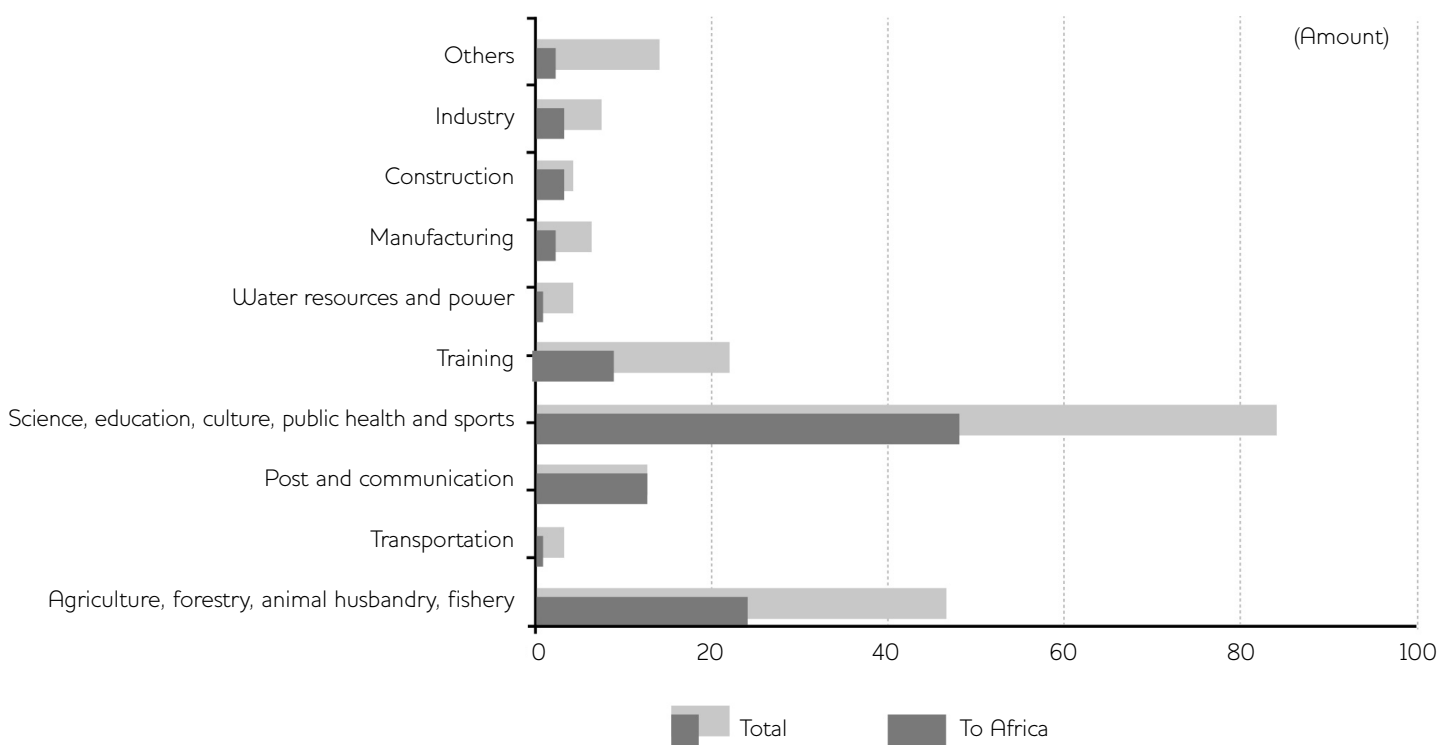

Source Author's own data sourced from China Commerce Yearbook. ${ }^{5}$

Figures 3 and 4 show China's foreign technical assistance projects by sector from 2003 to 2006.

\section{China's aid institutions}

At the core of China's foreign aid system are three ministries. The Ministry of Commerce

(MOFCOM) is the lead government agency responsible for China's foreign aid. Two subdivisions manage foreign aid-related work: the Department of Aid to Foreign Countries (DAFG), which comprises approximately 100 staff, with 20-30 working mainly on Africa (Davies, Edinger, Tay and Naidu 2008); and the Executive Bureau of International Economic Cooperation (EBIEC), which is organised as a public service unit to execute and implement the policies made at DAFC.

The Ministry of Foreign Affairs (MOFA) drafts and coordinates China's foreign policy under the central government. It plays an advisory role to MOFGOM on foreign aid, and works with MOFCOM in shaping specific aid packages, as well as organising major exchange events such as the Forum on China-Africa Cooperation (FOCAC). Finally the Ministry of Finance (MOF) drafts China's foreign aid budget in consultation with MOFCOM and MOFA, as well as being the contact agency for international financial institutions such as the World Bank and the International Monetary Fund (IMF), responsible for multilateral aid distributed through these channels.

Beyond the ministerial level, however, several institutional actors are also involved in foreign aid operations. These include central government agencies such as health and education; local government agencies; and Chinese embassies through the Economic and Commercial Counsellor's offices. The Export-Import Bank of China also plays a special role in providing Chinese government concessionary loans, as well as promoting an open and export-oriented economy through trade financing (Davies et al. 2008). Meanwhile, tens of thousands of Chinese enterprises, public and private; hospitals; educational institutions; NGOs; and other organisations are involved in on-the-ground delivery of aid projects in Africa, which is managed through a certification process by DAFC.

Major decisions related to foreign aid are usually made at the top level of the Chinese government, through the Central Working Group on Foreign Affairs, chaired by the president and vice president, and including the vice premier, state councillors and other relevant ministries. General policies and plans for foreign aid are drafted between the three major ministries, who have a working coordination mechanism on foreign aid; 
other working mechanisms also operate across and within other ministries and within ministries working on different aspects of foreign aid.

Much of China's engagement has been with African governments, conducted state to state through high-level visits and exchanges: from 2000-06, over 200 high-level visits took place between China and African countries (Horizon Group 2008). Summit diplomacy has been a unique feature of the China-Africa relationship. Such high-level visits not only improve understanding between China and African countries on important issues, they have also become opportunities to initiate or cement foreign aid projects, and the signing of major aid agreements almost always involves exchange of high-level visits.

\section{The Forum on China-Africa Cooperation} (FOCAC), established in 2000, has become an important mechanism for engaging in collective dialogue and cooperation between China and African countries. The third FOCAC, held in Beijing in November 2006, was a landmark in China's foreign aid relations with Africa, bringing representatives of 53 African countries to China, and the announcement of China's expansion of foreign aid and assistance to Africa. The fourth FOCAC was held in Egypt in November 2009, and the fifth and most recent FOCAC ministerial meeting was held in Beijing in July 2012. The forum has also become an important platform in extending 'summit diplomacy' to 'people diplomacy' through the involvement of NGOs and business people in these forums; since the second forum, joint business conferences have become a regular feature.

China has also been active in Africa's regional organisations, sending representatives and observers to the African Union (AU) summit in 2006. China is also a board member of the African Development Bank (AfDB) and other regional development banks. In May 2007 the AfDB had its board meeting in Shanghai, the first such meeting in China and only the second time when it was held outside Africa.

\section{The principles of China's aid}

As a developing country itself, China has built its foreign aid programme on the idea of mutual benefit and co-development. This was outlined in 'China's African Policy', released by MOFA in
2006, which emphasises principles of mutuality in friendship and cooperation, mutual benefits and common prosperity, and in mutual learning and development (MOFA 2006). By far the most comprehensive policy document on the ChinaAfrica relationship, this document outlines four broad areas of collaboration: political; economic; education and technology; and finally peace and security. As well as emphasising principles of non-conditionality in aid, the document is also interesting in its explicit endorsement of international collaboration towards the Millennium Development Goals (MDGs).

In 2011 China released a White Paper on Foreign Aid. The paper outlines a number of principles, which draws from China's foreign policy principles of 'Peaceful Coexistence', emphasising non-interference and non-conditionality, as well as the importance of mutual help and benefit. The principles also emphasise 'self-development' for recipient countries, framing foreign aid as a means for recipients to generate their own path to development independently.

\section{China's aid architecture: strengths and weaknesses}

\subsection{A practical development model}

Several distinctive features stand out in China's aid architecture and practice. Firstly, China's aid to developing countries, particularly to Africa, has had a strong practical orientation. Aid to Africa was initially used during the 1950-70s as a tool of foreign policy. Projects during this period focused very much on the immediate needs of African countries, infrastructure development, medical service, technical assistance in agriculture and so forth. While some major projects went beyond China's financial means at the time, many of the tangible outcomes became symbols of China's friendship with African countries. This pragmatism continued as China shifted its aid policy towards Africa in the late 1970s and in the late 1990s. China's domestic policy agenda made economic reform and development the top priority and mutual benefit and economic engagement became an important objective of foreign aid practice. Foreign aid began to reflect this new trend in promoting economic cooperation between China and African countries. Many of the companies involved in implementing the aid projects have accumulated substantial operational experience in African countries, which has proven valuable 
for their international reputation and growth, and in engagement in other commercial projects in developing countries (Horizon Group 2008).

This practical orientation means that China's foreign aid in general is not driven by a conceptual model of development, nor has China made much effort in generating such a model. Indeed, high-level Chinese government officials often remind their counterparts in Africa of the need to find their own way in developing their economy when they visit China and try to learn from China's experiences. China's development experiences have never been synthesised into a model, which contrasts with traditional Western donors, who put more emphasis on programme designs with articulated objectives based on certain conceptual models of development. Chinese government agencies involved in foreign aid, on the other hand, do not have a fixed model on how foreign aid should be done and rely heavily on their practical experiences in China.

This lack of dogma in China's development practice has been a strength in its foreign aid engagement, and makes them flexible and willing to accommodate the specific need of the recipient countries. However, the fact that, despite over 50 years of foreign aid practice, China still does not have a well-articulated model for its development assistance is also a significant flaw to its reputation and its aid effectiveness. One drawback to the heavily practical orientation of China's foreign aid, and the absence of a guiding theoretical model, is the lack of substantive and systematic research on development in this area. One issue is the lack of the consistent data necessary for such research. While there is evidence of the role China's foreign aid and engagement has played in, for example, Africa's rapid economic development, there is still a need for a coherent understanding of how China's foreign aid has worked, how China's aid differs from that of existing donors, and to what degree China's foreign aid is competitive or complementary to that of existing donors. Greater research and attention to the distinctive features of China's development assistance model can also enrich our understanding of the wider development process.

\subsection{Fragmented aid institutions}

The practical orientation of China's aid has led to the development of an aid architecture that supports such practice. As discussed, the overall policy direction on foreign aid is determined by a high-level working group in the central government. However, translating such general direction into policies that can be implemented relies heavily on MOFCOM, which, in turn, has to work closely with economic and commercial offices in embassies in African countries to identify and select the right projects, and to coordinate with relevant ministries to ensure that these projects are implemented with appropriate support and supervision. The common objective of the relevant institutions and working mechanisms are all geared towards tangible projects.

MOFCOM has been trying in recent years to improve existing and develop new regulations and standards related to the development and execution of projects. However, like most Chinese government agencies, the analytical capability within MOFCOM is relatively weak, and numbers of personnel working in development aid is low. It does not have the capacity nor the incentive to analyse the success and failure of the projects it has supported in a systematic way and to develop a coherent strategy for aid to Africa.

There is also a risk of overload in the foreign aid system, due to the problems and complexities of coordinating competing policy objectives. China's aid across the globe has increased dramatically over the last decade. In 2006 Chinese President $\mathrm{Hu}$ Jintao announced a plan to provide US $\$ 5$ billion in preferential credits and establish a US $\$ 5$ billion development fund to encourage and support investment by Chinese companies in Africa. These new plans have added to the workload of the relevant government agencies, with little significant change to the operations mode or substantial personnel increases, which puts the effective implementation of much of China's aid and investment policies at risk. Moreover, as China's aid broadens in nature, the horizontal fragmentation of development and aid responsibilities between government agencies increase transaction and coordination costs. As differing government agencies may also have competing policy objectives, dispersion of aid responsibilities puts further strain on the efficacy of the system.

This problem of fragmentation also goes beyond state organs. As global engagement has increased, as has the diversity of other Chinese organisations 
and businesses operating internationally. It is simply impossible for the government to monitor or regulate the activities of all these organisations, all of which have their own agendas and interests. However, for Africa and the developing world, all actors still reflect China and the Chinese government, who is perceived to be responsible for them. Wrongdoings by a single organisation generate significant negative externalities for the state and other Chinese organisations engaged in developing countries, despite the fact that they may be operating independently.

\subsection{Consistent aid principles}

A major feature of China's foreign aid practice is that despite the policy shifts over the years in China's foreign aid, the general principles that guide foreign aid practice have remained remarkably consistent since the Five Principles proposed by Zhou Enlai in 1953. China outlined its 'African Policy' in 2006, based on the same principles of equal treatment, respect for sovereignty, non-interference, mutual benefit and co-development (Li 2007: 74). Non-interference as a principle has proven controversial. For many Western countries, international aid is an effective tool to force African countries to move towards 'good governance' and 'democracy', in addition to other conditions, such as environmental standards, that are often attached to the aid provision. China's refusal to impose political conditions in its foreign aid has been seen as a threat to the effectiveness of these tools (Thompson 2005; Gill, Huang and Morrison 2007).

China's stance in this regard has been most welcomed by developing countries and China's aid is often used by African countries as a kind of leverage in their negotiations with Western donors. However, China's endorsement of these principles should not be read as an intent to undermine Western donors' aid strategy. China's lack of political conditionality stems in part from its particular historical experience of Western colonialism, as well as its own experience of political conditionality as a recipient of Soviet aid. These historical experiences have conditioned China's principles of non-interference, but China also upholds the belief that developing countries face complex challenges in development that no other country has solutions to. In cases of humanitarian crisis, China often relies on the judgement of legitimate regional or international organisations and joins such multilateral initiatives in addressing these issues in peaceful, non-coercive approaches.

Despite the benign rationale for the principle of non-conditionality, it has been one of the most controversial and most criticised aspects of China's foreign aid. As China and other 'new donors' in developing countries intensify their international aid activities, the 'traditional donors' have also stepped up their monitoring of activities by these new donors, and attempted to align them with existing consensus on aid principles as embodied in the Paris Declaration of the Organisation for Economic Co-operation and Development (OECD) Development Assistance Committee (DAC). China's principle of not attaching political conditions to its foreign aid is attacked when such aid is provided to governments that are considered corrupt and authoritarian, as non-conditionality is thus read as tacit endorsement. Environmental standards, employment of local labour and so on are also issues of concern in Africa, as well as Southeast Asia, and China's neglect of these issues hurts its credibility. While relevant government agencies have explained its rationale in adherence to the principles and practices, these arguments have not been compelling enough to reduce the critical voices, and the case of Darfur has only made things worse (Gill et al. 2007).

\subsection{High-level exchanges}

In international relations, summit diplomacy can often play unique roles in building trust and generating breakthroughs (Heap 2008). Analysts have noted that major meetings or 'summit diplomacy' between the Chinese and leaders of developing countries have been critical to establishing direct communication at the highest levels of government, setting the tone of relations and bilateral policies, and creating mutual trust and respect between heads of state (Li 2007). For example, for almost 20 years since 1991, Africa has been the destination of the Chinese foreign minister's first foreign visit. Major policy changes and aid projects are often announced during these high-level visits. The most recent summit visits by Chinese President Xi Jinping were to Tanzania, South Africa and the People's Republic of Congo in March 2013. During President Xi's visit to these African countries, he reiterated China's commitment to Africa, promised to continue to increase China's aid to Africa and signed a set of documents on aid and cooperation. ${ }^{6}$ 
Though great significance has been placed on highlevel visits and exchanges, mutual understanding and engagement on a societal level between China and other developing countries has been very shallow, partly due to the great differences in culture, religion and geographical distances. Compared with the frequent summit meetings between Chinese and African leaders, academic and cultural exchanges remain very limited, and important high-level exchanges have not translated into broader societal and cultural exchange. Chinese art and cultural exchange programmes are criticised for not adapting to target local populations, and in both China and African countries, media portrayal and public perceptions are still somewhat distorted and framed by stereotypes. The slow development of NGOs and civil society in China also puts constraints on further grassroots exchanges between those in China and other developing countries.

Academic research and information is also lacking: while in Western institutions, studies on Africa have been increasing in recent years in light of China's intensifying engagement, such systematic and in-depth studies are still lacking within China, and research institutions generally rely on Western data and original research. General information and cultural understanding on Africa is also lacking within China, and alongside poor media portrayal, online interactions between China and Africa over the internet are also weak.

\section{Emerging challenges in China's foreign aid landscape}

These distinctive features of Chinese aid have played an important role in building China's success and reputation as a foreign aid actor. However, as African development has been ascending rapidly as a global agenda issue, the landscape of international aid has also changed. The political and economic environment in African and other developing countries are also experiencing fundamental change, and as China's engagement with developing countries deepens, there are also increasingly diversified and sometimes competing interests among different government agencies, major public enterprises, small private entrepreneurs, NGOs and other groups. Managing these growing pains in China's engagement with Africa and other developing countries also poses new challenges. The aid architecture that has worked well during the past half-century needs to adapt to meet these new challenges.

\subsection{Perception of China as a new petropower}

Despite China's broad engagement with Africa, engagement with Angola, Nigeria and Zimbabwe has received particular attention, partly because these countries are considered as very corrupt and politically unstable, as well as being resource-rich. Such perceptions have permeated throughout some African and other countries and seriously damaged popular attitudes to China, most notably in Zambia, where the 2006 elections saw a candidate stand on an explicit and critical antiChina, anti-India platform (Davies et al. 2008), and issues of labour rights and environmental standards continue to cause tension. The lack of engagement with African civil society exaserbates the situation. A telling example is the result of a media survey conducted by the School of Journalism and Communication of Tsinghua University during the Beijing Olympics in 2008. The survey found that in Olympics reports from different regions around the world, Africa showed the highest level of negative reporting (56 per cent).

\subsection{Risk management in developing countries}

Though China's engagement with Africa is growing rapidly, the risks and realities of political instability in such developing states must still be recognised and managed. Though China's 'Going Global' policy has mainly driven the expansion of its larger firms and corporations, much of the new investment and commerce in developing countries in Africa have come from small- and medium-sized enterprises (SMEs) and private entrepreneurs. These small enterprises are not directed by the state, and often face large information asymmetries and lack local knowledge when trying to operate in developing countries. Aside from local Chinese embassies, there are few other information channels to guide their transition or operations abroad.

\section{Reforming China's foreign aid: some recommendations}

Given the rapid expansion of China's foreign aid and investment activities in Africa and the developing world, from both the state and business sector, there is a risk of overload to its aid institutions, as well as risks to China's credibility and reputation as a development actor and as a rising power. There is a need to strengthen and consolidate China's aid institutions, to better 
define China's aid model and principles, and to facilitate more active engagement with the international community and with African societies.

\section{Create a working committee on international aid at the State Council level to enhance policy development and coordination}

As China's international aid budget grows, there is an urgent need for better policy development and coordination. At the State Council level, the creation of a working committee on international aid with a substantive and relatively independent secretariat would raise the profile of international aid and enhance policy development and coordination. The secretariat should have core research capability so that it can provide analytical support for policy development and evaluation on China's foreign aid, developing the capability to survey the field and make use of the existing literature and in order to distil policy lessons. One necessary function for the secretariat would be the development of a consolidated databank, which currently does not exist, that would account for all of China's foreign aid activities.

It is possible that within the not-too-distant future, this secretariat, along with DAFC in MOFCOM, could evolve into a Chinese international development agency with a substantive aid budget (Chinese CIDA), paralleling the development of such agencies in most developed countries with its own substantial aid budget (USAID in the USA; DFID in the UK; CIDA in Canada; JICA in Japan and so forth). Among the 'new donors', South Korea has already established an international aid agency, the Korea International Cooperation Agency (KOICA), in 1991. China's decentralised and fragmented aid institutions are still behind in this regard.

\section{Establish thematic programmes in implementing China's foreign aid}

China's foreign aid includes grant aid, interest-free or concessionary loans, and assistance for joint ventures or cooperation. These aid programmes are provided mostly in the form of projects which are typically generated in a bottom-up fashion. As China's aid programmes have expanded rapidly in recent years, China needs to establish some thematic programmes in either DAFC or EBIEC, to complement the bottom-up process. Such thematic programmes can help to better align aid projects with policy objectives, improve the coherence of aid projects, and create learning opportunities to build capacity within DAFC and EBIEC in specific aid fields. In the long run, it might be a good idea to shift all grant aid to thematic programmes to maximise the policy impact.

\section{Engage actively with the existing international aid community through dialogue, understanding and cooperation}

In the international development market, China does not have the baggage some of the Western colonial powers carry, to its advantage. However, in a globalised world, China's increased foreign aid activity will generate significant impacts for the aid activities of the existing international aid community. Engaging the existing international aid community offers China new opportunities to learn from the experiences of the traditional donors and collaborate with them to generate greater positive impact. This does not mean China need necessarily subscribe to the existing rules and regulations set by traditional donors. In recent years, there have been increasing collaborations between Chinese international aid agencies and the existing international aid community. For example, the World Bank and the China EximBank signed a Memorandum of Understanding (MoU) in 2007 aimed at enhancing collaboration on road and energy investment projects in Uganda, Ghana and Mozambique. Future active engagement through dialogue, understanding and cooperation provides opportunities for Chinese aid agencies and scholars to better articulate China's aid position and deflect criticism, as well as an opportunity to also shape current Western practices of aid.

\section{Create a group of interdisciplinary research centres for regional studies in Chinese universities}

There is currently a pressing need for China to develop its own research capabilities in different regions of the world, including Africa. Traditionally, such work was mostly done in the language departments of different universities, as well as by relevant research institutes in the Chinese Academy of Social Sciences (CASS). China's expanded engagement across the world requires a new generation of scholars with regional and linguistic experience, as well as research proficiency in interdisciplinary social science research in these regions. The establishment of a network of research centres with coordinated regional focus in universities would meet this demand. These centres should provide academic training for practitioners in international development. Currently, the 
Ministry of Education already has a network of centres of excellence in humanities and social science disciplines through a competitive process, and there is space for this process to be accelerated.

\section{Enhance exchanges and collaborations among the academic community, civil society and opinion leaders in China and the developing world}

Though official and summit meetings have been a cornerstone of relationships between China and developing countries, at the same time, scholars, civil society and other non-state actors are becoming more important in shaping public opinions and political decisions. At present, exchanges and collaborations between Chinese scholars and scholars from other countries and civil societies are generally only made possible by a third party. Greater engagement and collaboration in the academic community and civil society in the developing world is needed, both in producing the research and information

\section{Notes}

* This article is based on a report comparing India and China's foreign aid practice, partially supported by the International Development Research Centre (IDRG). Able research assistance was provided by Chenni $\mathrm{Xu}$, Hanzhi Yu and Robert Dietrich. The author is particularly grateful to Yunnan Chen, research officer at IDS, for her editing work. Any errors, however, are the author's.

1 Ministry of Commerce China Commerce Yearbook (2003, 2004, 2005, 2006), www.yearbook.org.cn/ english/yearbook_view/2007/2007contents.htm.

2 Ministry of Commerce China Commerce Yearbook (2003, 2004, 2005, 2006), www.yearbook.org.cn/ english/yearbook_view/2007/2007contents.htm.

\section{References}

Chen, Shuang (2008) Improve China's Bilateral Aid to Africa, PAE Report, Cambridge MA: Kennedy School of Government, Harvard University

Davies, Martyn; Edinger, Hannah; Tay, Nastasya and Naidu, Sanusha (2008) How China Delivers Development Assistance to Africa, Stellenbosch: Centre for Chinese Studies, University of Stellenbosch

Gill, Bates; Huang, Chin-Hao and Morrison, J. Stephen (2007) 'Assessing China's Growing Influence in Africa', China Security 3.3: 3-21

Heap, Peter C. (2008) Globalization and Summit Reform: An Experiment in International Governance, New York: Springer resources that would benefit China's aid practitioners and entrepreneurs operating in developing countries, but also in promoting greater cross-cultural understanding between China and Africa, and an opportunity to better China's international image in African societies.

Despite the global financial crisis, Chinese leaders have reiterated China's commitment to Africa. As China is becoming a large and stable donor internationally, it must learn how to improve the institutional arrangements of its aid system in order to maximise the positive impact of its foreign aid and investment. This research outlines the parallel strengths and weaknesses in China's current aid practices, and offers some concrete recommendations for its future evolution. However, as China's aid activities grow and the development landscape changes, there is still a consistent need for future research on this ever-shifting issue.

3 Ministry of Commerce China Commerce Yearbook (2003, 2004, 2005, 2006), www.yearbook.org.cn/ english/yearbook_view/2007/2007contents.htm.

4 Ministry of Commerce China Commerce Yearbook (2003, 2004, 2005, 2006), www.yearbook.org.cn/ english/yearbook_view/2007/2007contents.htm.

5 Ministry of Commerce China Commerce Yearbook (2003, 2004, 2005, 2006), www.yearbook.org.cn/ english/yearbook_view/2007/2007contents.htm.

6 http://politics.people.com.cn/n/2013/0411/ c1001-21093460.html.

7 www.tsinghua.org.cn/alumni/infoSingle Article.do?articleId $=10017073 \&$ columnId $=$ 10005544.

Horizon Group (2008) China's Engagement with Africa: PPT Presentation Based on a Survey Report, www.horizon-china.com (accessed 15 May 2014) Li, Anshan (2007) 'China and Africa: Policies and Challenges', China Security 3.3: 69-93

MOFA (Ministry of Foreign Affairs) (2006) 'China's African Policy', People's Daily Online, http://english.peopledaily.com.cn/200601/12/ eng20060112_234894.html (accessed 15 May 2014)

Thompson, Drew (2005) 'China's Emerging Interests in Africa: Opportunities and Challenges for Africa and the United States', Africa Renaissance Journal 2.4: 20-29 